\title{
China-Myanmar Bilateral Relations: An Analytical Study of Some Geostrategic and Economic Issues
}

\author{
Akkas Ahamed \\ Associate Professor, Department of Political Science, University of Chittagong, \\ Chittagong-4331, Bangladesh, \\ E-mail: ahamedcu@yahoo.com
}

Md. Sayedur Rahman

Assistant Professor, Department of Political Science, Faculty of Social Sciences, Begum Rokeya University, Rangpur -5400, Bangladesh \& Masters Student, Master's Programme in Socioeconomic and Political Development of Modern Asia, Faculty of World Economy and International Affairs, National Research University Higher School of Economics, Moscow,

Russian Federation,

E-mail: sayedur34@gmail.com

Nur Hossain

Assistant Professor, Department of Political Science, Chittagong Cantonment Public College, Chittagong, Bangladesh,

E-mail: nhccpc10@gmail.com

Received: Aug. 17, 2020 Accepted: Sept. 7, 2020 Online published: Sept. 16, 2020

doi:10.5296/jpag.v10i3.17704 URL: https://doi.org/10.5296/jpag.v10i3.17704

\begin{abstract}
Myanmar's geopolitical and geostrategic position is very important for China and India, the two regional powers in East Asia and South Asia. Myanmar is the main connecting hub for South Asia, East Asia, and Southeast Asia, and it is also connected with the Bay of Bengal and the Indian Ocean. Myanmar is connected with the two corridors of China's ambitious projects, Belt and Road Initiative (BRI), and Bangladesh, China, India, Myanmar Economic Corridor (BCIM). Chinese ships have to navigate at the Malacca Strait, especially in the case of fuel oil imports and exports to global markets, which are, both times consuming and
\end{abstract}


strategically risky. But, using the Rakhine state's Kyaukpyu port will reduce China's dependence on the Malacca Strait and expand trade. Due to the US presence in the Indian Ocean, the recent Sino-Indian conflict, and Myanmar's geostrategic position, Sino-Myanmar relations are now one of the topics of study. This article will analyze the geostrategic and economic issues of Sino-Myanmar relations. The study has found that both China and Myanmar have greatly been benefitted through the establishment of strong bilateral relationship based on trade and investment, connectivity, constructions of ports and special economic zones. The main objective of this study is to find a diplomatic way to improve the Bangladesh-Myanmar relations based on the results of the strong relationship of China and Myanmar. This study is a major contribution to the field of China-Myanmar bilateral relations in the context of some geostrategic and geo-economic issues. The study has been carried out based on secondary data with some primary data of border survey and focus group discussions. At the conclusion of this study, there has been provided with some policy recommendations to improve the geostrategic and economic relations between the two neighboring countries.

Keywords: China, Myanmar, Border relations, Geo-strategic, Economic, Natural resources, Bay of Bengal

\section{Introduction}

China and Myanmar are two geographically bordering countries with a common border of $2165 \mathrm{~km}$. Other neighboring countries of Myanmar are: Bangladesh, India, Thailand and Laos. The relationship between the two countries in Southeast Asia and East Asia is very important, especially for geopolitical, economic, and strategic reasons. The rise of China as a new world power after the collapse of the Soviet Union against the domination of the US imperialist power in the current world system is the subject of a new study in geopolitics. Over the past few decades, especially in South and Southeast Asia, China has continued to cooperate financially and militarily with neighboring countries in order to increase its dominance (Ahamed \& Rahman, 2020). Bilateral relations with China, the world's second largest economy (GDP US\$ 14.140 Trillion, 2019) and Myanmar, the 73rd largest economy (GDP US \$ 69.994 billion, 2019) are very important. China has been playing an important role in Myanmar's economic development through bilateral trade relations since 1988. From 1988 to 2018, 26\% of all foreign investments in Myanmar came from China, and by June 2020, Chinese investment in Myanmar was US \$ 21350.668 Million (DICA, 2020).

In order for China to emerge as a new world power, it is very imperative to establish its control in the region, especially in the Indian Ocean, and the Bay of Bengal in the aspect of geopolitics and geo-economics. Due to its location in the Bay of Bengal, and the Indian Ocean to the south of Myanmar, Myanmar is important to other Western powers, including India. The Indian Ocean, in particular, is rich in natural resources, accounting for 62 percent of the world's natural resources, such as fuel oil, 35 percent natural gas, 40 percent gold, 60 percent uranium, and 80 percent diamond (Ahamed \& Rahman, 2020). In that case, Myanmar is one of the means to realize China's geostrategic and geo-economic interests. As a result, since the Chinese Revolution on October 1, 1949, it has been playing a vital role in 
Myanmar's economic development on the basis of bilateral relations. China is one of the Myanmar's partners in trade and investment and exports-imports. From 2009 to 2019, Myanmar's exports to China were \$5. 71 million and China has invested 21 billion as of March 2020 (DICA, 2020). Following the 70th anniversary of Sino-Myanmar diplomatic relations, Chinese President, Xi Jinping visited Myanmar, and signed 33 bilateral trade agreements in various sectors, signaling a new milestone in Sino-Myanmar relations.

On the other hand, China and Myanmar have become tested friends for strategic reasons. Myanmar became economically isolated from the rest of the world after the August 8, 1988 student-public uprising, and the subsequent military coup. As the United States shunned world trade, especially in the face of economic sanctions from the European nations, China expanded its ties with Myanmar for strategic reasons and invested in all areas, including military, natural resources, industry, agriculture and infrastructure development. The US-India alliance's growing surveillance on the South China Sea and the Indian Ocean requires alternative communication to keep the wheel of China's economy moving. In particular, one of the main components of China's economy is fuel oil, which China imports from various countries, including the Middle East and Africa, and enters into China through the Malacca Strait. But China's dependence on the Malacca Strait for imports and exports is strategically risky. That is why Myanmar is the gateway to connect China with Asia, Africa, Europe, and the Middle East to implement China's ambitious Belt and Road Initiative (BRI). As part of the BRI project, the China-Myanmar Economic Corridor (CMEC) will also connect Kunming, the capital city of the Chinese border province of Yunnan, to Mandalay, the central province of Myanmar, to Yangon in the south, and Kyaukpyu port in Rakhine State in the west. To that end, China has invested US \$ 9 billion in railways in Myanmar, US\$ 1.68 billion in New Yangon Town and US\$ 10 billion in the Port and Special Economic Zone project (Frontier, 2019). This will allow China to continue importing and exporting fuel oil without the influence of India, and the United States, avoiding the use of the Malacca Strait.

In contrast to China's growing influence in Myanmar, India has undertaken several projects, most notably, the Kaladan Multi-Model Project. There are also a number of projects of Japan and Russia in Myanmar. Stability in Rakhine State is needed to keep these projects going. For this reason, China has vetoed Myanmar's various resolutions on the Rohingya genocide in 2017, ignoring world criticism, while India and Russia have remained silent. At the same time, not only Myanmar, but, also Bangladesh is geo-strategically important to China, in which China became the highest foreign investor in Bangladesh by investing US \$ 1159.42million (1.16 billion) in various economic projects in FY 2018-2019, which was 130\% more than the last FY 2017-18, (The Financial Express, 2020). In the wake of the recent Sino-Indian conflict, China has taken steps to strengthen ties with neighboring countries, and has continued to provide $97 \%$ tariff exemption on 5,161 Bangladeshi products in the different Chinese markets (The Daily Star, 2020). In this article, we will discuss various aspects of China-Myanmar relations in the context of some geo-strategic and geo-economic cooperation, and identify the obstacles and determine the future course of action. 


\section{Objectives of the Research}

1. To analyze the importance of Sino-Myanmar relations in the context of geo-political, geo-strategic and economic issues;

2. To analyze the historical context of Sino-Myanmar relations;

3. To identify China's economic and political interests in Myanmar;

4. To analyze the bilateral relations of the neighboring countries with Myanmar;

5. To identify obstacles to Sino-Myanmar relations and determine the future course of action;

6. The Sino-Myanmar relations are also related to Bangladesh's geo-strategic and economic interests in the region. It is very important to understand the Sino-Myanmar relations for Bangladesh's foreign policy; because Bangladesh-Myanmar relations are somehow related to Sino-Myanmar geo-strategic relations.

7. To provide some policy recommendations to Bangladesh government based on the results of the study of Sino-Myanmar relations.

\section{Methodology of the Research}

The research work has been done in a qualitative approach. The various data used in this research, have been collected from primary and secondary sources. In that case, information has been collected from the different research articles, journals, magazines, newspapers, archives, video records, various online portals related to the subject. Data have also been collected from the different research works stored in various libraries in the country, including online libraries. The topic has also been analyzed based on the researchers' own experience. Besides, we have surveyed the Bangladesh-Myanmar border, and Bangladesh-India border, where we have collected some important data related to the Sino-Myanmar relations. We have also exchanged views with some people on Sino-Myanmar relations. But field level primary data have been employed in this research in qualitative and observation methods instead of quantitative approach.

\section{Historical Background of Sino-Myanmar Relations}

China-Myanmar relations have existed since ancient times. This relationship dates back to the establishment of the Pagan Kingdom in 489 BC (Taylor, 1987). But, when the Mongols came under the Yuan Dynasty (1271-1368) their relations were deteriorated. This relationship lasted until the advent of Western imperialism, although, there were subsequent isolated revolts (Taylor, 1987). With the fall of the last Burmese king in 1885, Myanmar became a full-fledged British colony. The last king of China, Qing, fell in 1911. Myanmar gained independence from the British in 1948, and China established a socialist government through the Mao Zedong's Revolution on October 1, 1949. Sino-Myanmar diplomatic relations were established on June 8, 1950, with China, being recognized as the first communist country. Especially during the World War II, the Yunnan-Burma border was opened to help protect the Japanese from the British aggression, which reaffirmed Sino-Myanmar relations. India and the United States helped Tibet during the 1954 civil war in Tibet. A treaty was signed on the 
basis of five principles aimed at ending the war. Which was later incorporated into the Sino-Myanmar Joint Declaration on June 29, 1954. These policies were adopted at the Non-Aligned Movement Conference in Bandung, Indonesia in 1955. The main Principles of the conference were:

1. To protect territorial integrity and sovereignty on the basis of mutual respect;

2. One state should not invade another state;

3. One state should not interfere in another's internal affairs;

4. Ensuring equality and mutual benefits;

5. Peaceful coexistence and dispute resolution (Geng, L. 2006).

China and Myanmar maintained friendly relations between 1950 and 1960, with two exceptions, the first being Burma's neutral foreign policy during the Sino-US conflict, and the second being China's support for the rebel Communist Party of Myanmar. In the wake of Myanmar's internal strife and opposition, General Ne Win took power in 1962, imposed martial law, and nationalized all private businesses in the state (except agriculture). The main goal of the nationalization policy was to expel Myanmar's South Asian, and Chinese immigrants from the country. As a result of this policy, millions of people, including about one million Sino-Burmese, have fled the country. During this time, Sino-Myanmar relations were deteriorated. Particularly in 1967, when the Chinese opposition clashed with the pro-Chinese Communist Party of Burma (CPB), when the law and order situation were deteriorated drastically (Bert, 2004). After this incident, the Chinese Communist Party began openly supporting the Communist Party of Burma, which resulted in the occupation of the Chinese border province of Shan in 1973 by communist rebels, which had long been a source of panic for Myanmar (Bert, 2004). After Deng Xiaoping came to power, Chinese supports for the Burmese communist rebels were withdrawn. Kokang, Kachin, Shan, and Mong La border rebel groups were encouraged to negotiate a ceasefire agreement with the Burmese military government. As part of the ceasefire, the rebel tribes were granted autonomy in the border states of Shan, and Kachin, which were later incorporated into the 2008 constitution. The 1988 students' and pro-democracy movements led to widespread violence across the country. To control this situation, the State Law and Order Restoration Council (SLORC), was formed, and the SLORC came to power in Myanmar. At this point, the main rebel group, the Burma Communist Party (BCP), split into four groups (Lintner, 2000).

The military-backed government used military force to control the situation, killing many people and making mass arrests. In this situation, President Ne Win resigned, and announced the democratic election. In the 1990 election, Aung San Suu Kyi's political victory was won, but the military re-established martial law without handing over state power. In the wake of this incident, other Western states, including the United States, imposed economic sanctions on Myanmar, and cut diplomatic relations, leaving Myanmar virtually isolated from the rest of the world. On this occasion, promotion of border trade with Myanmar was initiated, and three trade posts were set up along the border with the aim of strengthening relations with Myanmar in order to establish its own economic and geo-strategic interests. Myanmar's 
relations with China grew steadily from 1998-2008. During this time, China emerged as an investor in Burma in a variety of areas, including military equipment sales, and training, power plantation, energy, and infrastructure development (Zhou \& Cuyvers, 2011). The establishment of a semi-civilian government led by President Thein Sein on March 23, 2011 eased China's monopoly power over Myanmar. Myanmar is trying to establish diplomatic relations with the western world through various political channels. Following this, Chinese President Thein Sein visited the White House, and, for the first time in history, US President, Barack Obama visited Myanmar in 2014 (Weifeng, 2016). Myanmar-Chinese mega projects continue to reduce costs and Myistone hydropower projects are scrapped in the face of public outcry (Fuller, 2011).

About $\$ 1$ billion in project costs were cut in FY 2012-13. However, in 2017, the Rohingya people in Rakhine State were forced to flee the country due to torture, rape, and genocide by the military force of Myanmar. And, for the persecution of Rohingya minorities, Myanmar had to face new international sanctions from the Western world. As a result, Myanmar's dependence on China has started a new, and Sino-Myanmar trade relations have reached new heights, in recent times. As a result, on January 18, 2020, Chinese President Xi Jinping visited Myanmar almost two decades later, and signed 33 agreements aimed at boosting its bilateral trade (South China Morning Post, 2020).

\section{Sino-Myanmar Relations in the Context of Geopolitical and Geostrategic Issues}

Neighboring Myanmar is geopolitically and geo-strategically important for maintaining China's position as a superpower in world politics, and accelerating economic development. Myanmar is the connecting bridge of China's luxury project, Belt and Road Initiative (BRI). China has about $2185 \mathrm{~km}$ of border with Myanmar, in terms of geographical location. Good relations with Myanmar, Laos, Cambodia, Thailand, and Vietnam as neighboring countries are very important for the countries of South Asia and Southeast Asia to make them free from the growing influence of China's arch-enemy, the United States, and to expand trade. Myanmar is of great importance to China for its geo-strategic reasons for continuing its imports of fuel oil from the Middle Eastern and African countries, and to export Chinese goods to different parts of the world. Because, over the past two decades, 80 to 85 percent of China's trade have been done through the sea. One of the means of communication in China is the Malacca Strait, which is not safe for strategic reasons. China has long sought alternatives to imports and exports to keep its economic activities normal, especially in the Indian Ocean and the South China Sea, due to the growing influence of other enemy states, including the United States. And the implementation of China's different projects is located in Myanmar. A link road will be built from Kunming, the capital of China's southern province of Yunnan, to Kyaukphyu in the Rakhine state of Myanmar. In 2009, China and Myanmar agreed to build a crude oil pipeline and a natural gas pipeline with an investment of US \$1.5 billion and US $\$ 1$ billion (Han, 2020). This will connect China with the Bay of Bengal, Indian Ocean and the Arabian Sea, and save about two weeks in terms of transportation of goods, and reduce the distance to about two thousand kilometers. It will also reduce the interference of the Western world in the transportation of imports and exports of the different goods. 


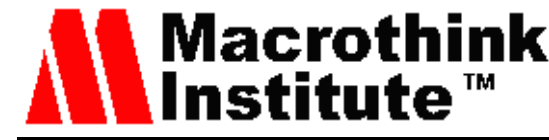

\section{Map: 1 (Strait of Malacca)}

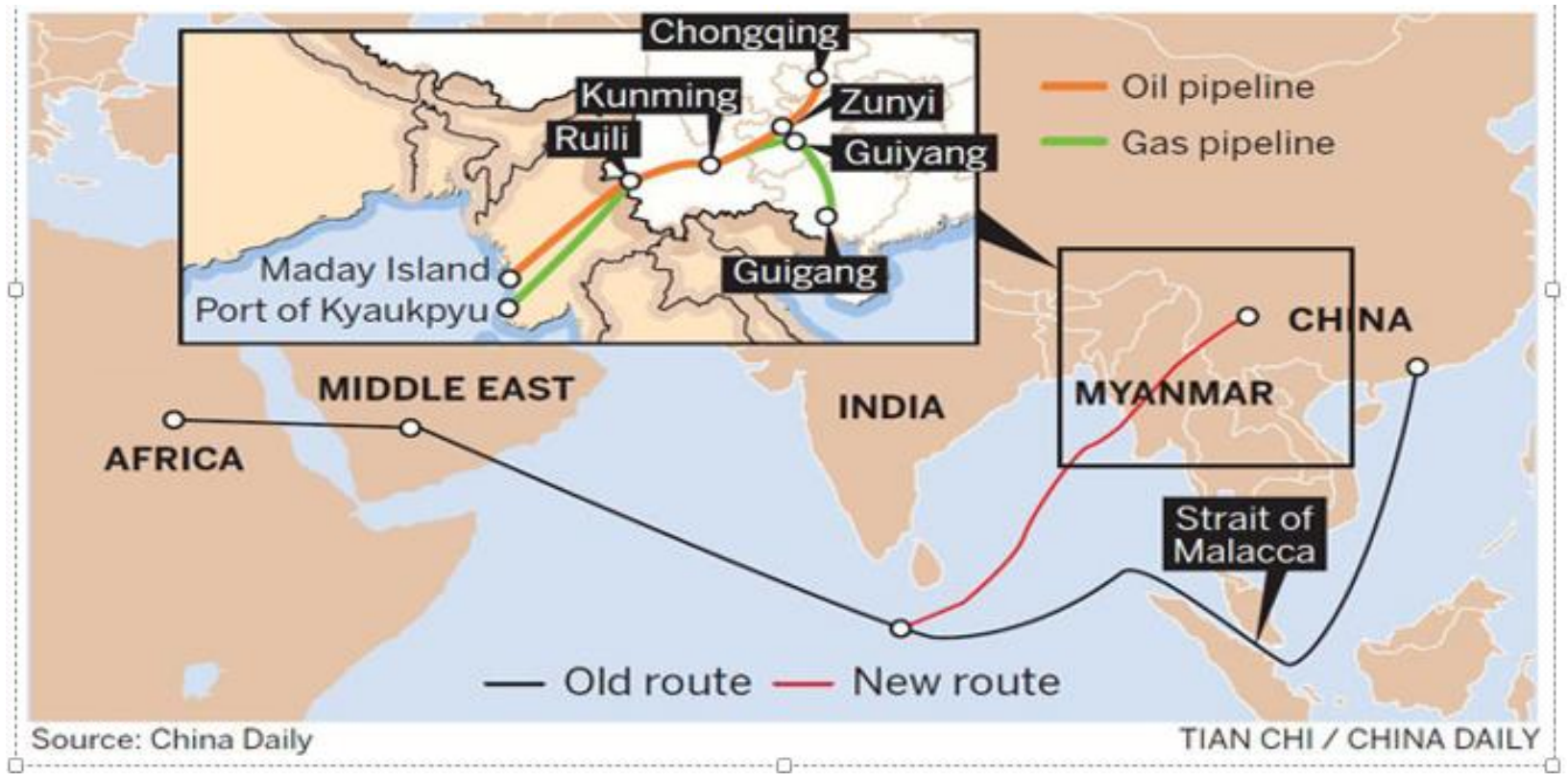

Source: https://ian56.blogspot.com/2017/05/myanmar-oil-gas-pipeline-to-china-opens.html

However, from a geo-strategic point of view, China-Myanmar relations are as important for China as they are for Myanmar. Chinese investment has increased several hundred times due to the BRI project in Myanmar, which is isolated from the international arena. Geopolitically, Myanmar is important not only to China but also to the United States, India, Russia and the rest of the Western world. But, the Western world wants to hinder China's economic rise. That is why the United States has entered into a military agreement with India to increase its dominance in Southeast Asia and South Asia, including the Indian Ocean, which is one of China's concerns. Also the USA has military bases in Japan, and other neighboring countries. For these strategic reasons, China has chosen Myanmar as an alternative trade route. In March 2009, the China-Myanmar-Kunming to Rakhine oil and gas pipeline was agreed upon at a cost of US \$ 1.5 billion and US \$ 1.04 billion respectively (Weifeng, 2016).

\section{China-Myanmar Economic Corridor (CMEC)}

The China-Myanmar Economic Corridor (CMEC) will be strategically and economically linked with China through trade links with more than 60 countries in Asia, South Asia, Africa, the Middle East and Europe. The CMEC plan was announced at a meeting of Chinese Foreign Minister, Wang Yi and Aung Sun Suu Kyi in November 2017, and a 15-point MoU (Memorandum of Understanding) was signed (Ramachandran, 2019). China hopes the project will connect the landlocked province of Yunnan to the Bay of Bengal and play an important role in China's economic development and geostrategic cooperation, as well as it will increase China's military power and trade in the Indian Ocean. As part of the project, it has already continued to transport fuel by laying pipelines to transport gas in 2013 and oil in 2017. 


\section{Macrothink}

\section{Map: 2 (China-Myanmar Oil and Gas pipeline)}

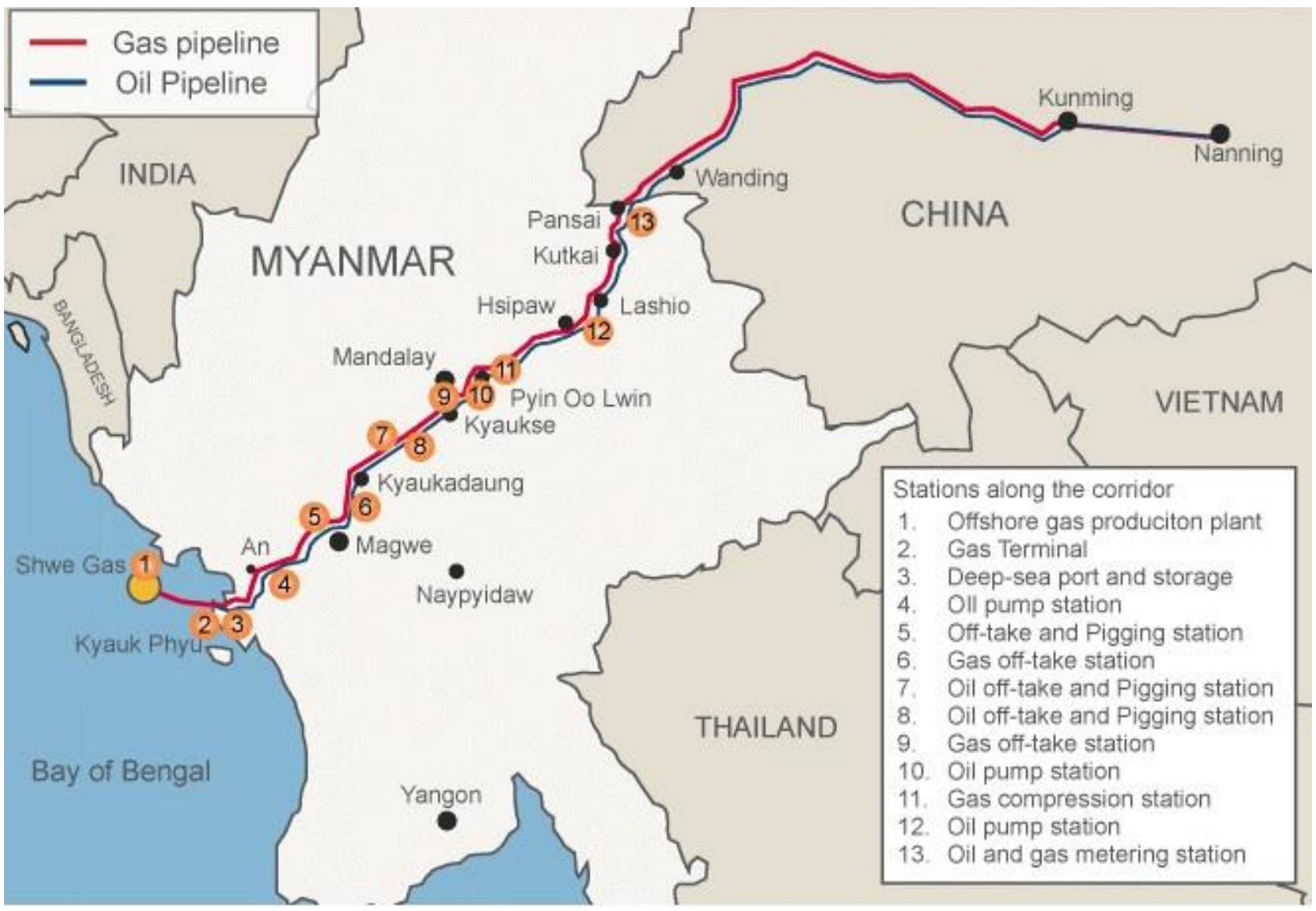

Source: https://deepresource.files.wordpress.com/2015/11/china-pipelines.jpg

On the other hand, geostrategically the project would reduce China's dependence on the South China Sea and the Malacca Strait for trade, and protect China from future attacks by rival states, including the United States. Although, China's strategic advantage over the project is high, many in Myanmar believe that it will lead to weaken the Myanmar's economy and infrastructural changes (Ramachandran, 2020). Many see the project as a way to expand China's trade and create employment opportunities (Frontier Myanmar, September 26, 2018). Although, this project has emerged as a major concern for the Myanmar government due to the high cost which is difficult to repay later. Under the project, the Muse-Mandalay planned railway will cost about US \$ 9 billion (The Irrawaddy, May 14, 2019), New Yangon city project will cost US \$ 1.68 billion (Frontier Myanmar, March 8, 2019), Kyaukphyu port project will cost US \$ 10 billion ( $\$ 7.3$ billion for port and $\$ 2.7$ billion for the SEZ) (Ramachandran, 2020). However, experts believe that this huge Chinese investment will increase the debt burden on Myanmar and increase Myanmar's dependence on China, which in many cases, could lead to Sri Lanka's fate (Mizzima, 2020). In addition, these projects will result into massive economic activity, environmental disasters, local land acquisition and displacing people. Fishermen are also worried about losing their livelihoods due to the ban on the fishing at sea (Mizzima, 2020). 


\section{Sino-Myanmar Border Trade Relations}

Several hundred years ago, the South-West Silk Road was used for trade and commerce as a link between China, Myanmar and India. For a long time, China exported Myanmar silk, porcelain, tea and metals, and imported coins, spices, wood and jade from its neighbors. But, now the business model has changed and China is exporting a huge number of equipment, mechanical and electrical products, textiles, motorcycle parts and chemicals to Myanmar and importing logs, sawed timber, agricultural products and minerals from Myanmar. Myanmar's exports to China were US\$5.71 Billion during 2019, according to the United Nations COMTRADE database on international trade. Myanmar imports from China were US $\$ 6.45$ Billion during 2019, according to the United Nations COMTRADE database on international trade (Trading Economics, 2019).

At the same time, Myanmar is one of the poorest countries in South East Asia, due to the isolation from the international community, and internal mismanagement. The country lags behind in foreign investment due to its poor infrastructure and communication system. Until 2012, Western economic sanctions were in place, with no country other than China investing heavily in Myanmar. In recent times, India and China have increased their investments in Myanmar, resulting in a slight increase in Myanmar's imports-exports trade. Myanmar mainly exports agricultural products, animal products, marine products, minerals and forest products and manufactured goods. And the country imports capital goods, intermediate goods, industrial raw materials and consumer goods (Hoque, 2016).

On the other hand, most of the Sino-Myanmar trade is done through the border. Trade across the border reached US 8.6 billion in the first 10 months of the fiscal year 2019-2020, which began in October, according to figures released by Myanmar's Ministry of Commerce. At the same time, Myanmar's exports were US \$ 5.8 billion and imports were US \$ 2.7 billion. The trade growth for the fiscal year increased to $\$ 8.3$ billion from 281 million in the fiscal year of 2018-19 (Xinhua, 2020). China-Myanmar trade is conducted along the border areas of Muse, Lweje, Kanpikete, Chinashwehaw, Kengtung. Thai-Myanmar trade is conduced along the border areas of Tachilek, Myawady, Kawthoung, Myeik, Hteekhee, Mawtuang and Maese. Bangladesh-Myanmar trade is conducted along the border areas of Sittwe and Maungdaw. Indo-Myanmar trade is done along the border areas of Tamu and Reed border. China accounts for the lion's share of Myanmar's border trade. Since the founding of Myanmar, China has become Myanmar's sole rescuer due to the repeated international economic sanctions. According to the United Nations Comtrade, Myanmar exported US \$ 5.71 billion to China in 2019 (Trading Economics, 2019). 


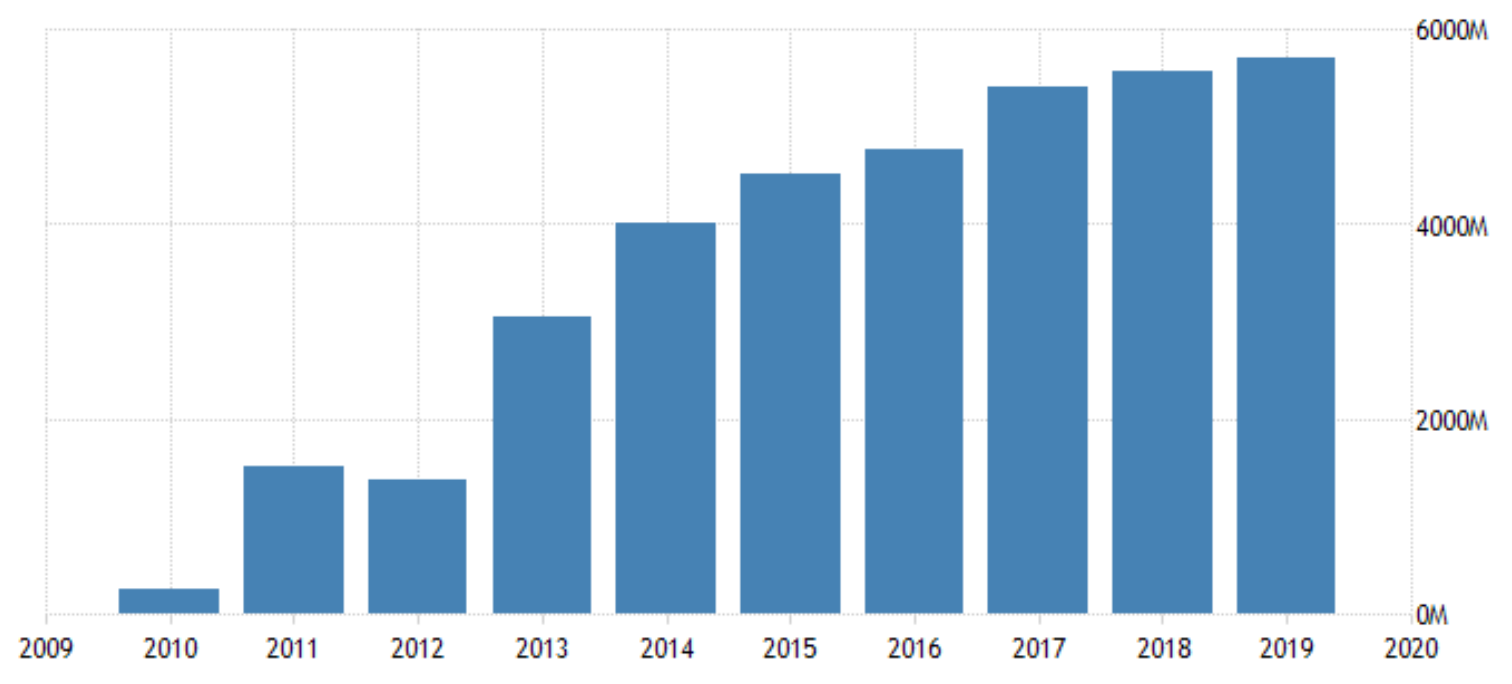

Figure 3. (Myanmar's Exports to China)

Source: https://tradingeconomics.com/myanmar/imports/china

On the other hand, Myanmar has imported US \$ 6.45 billion from China till 2019.

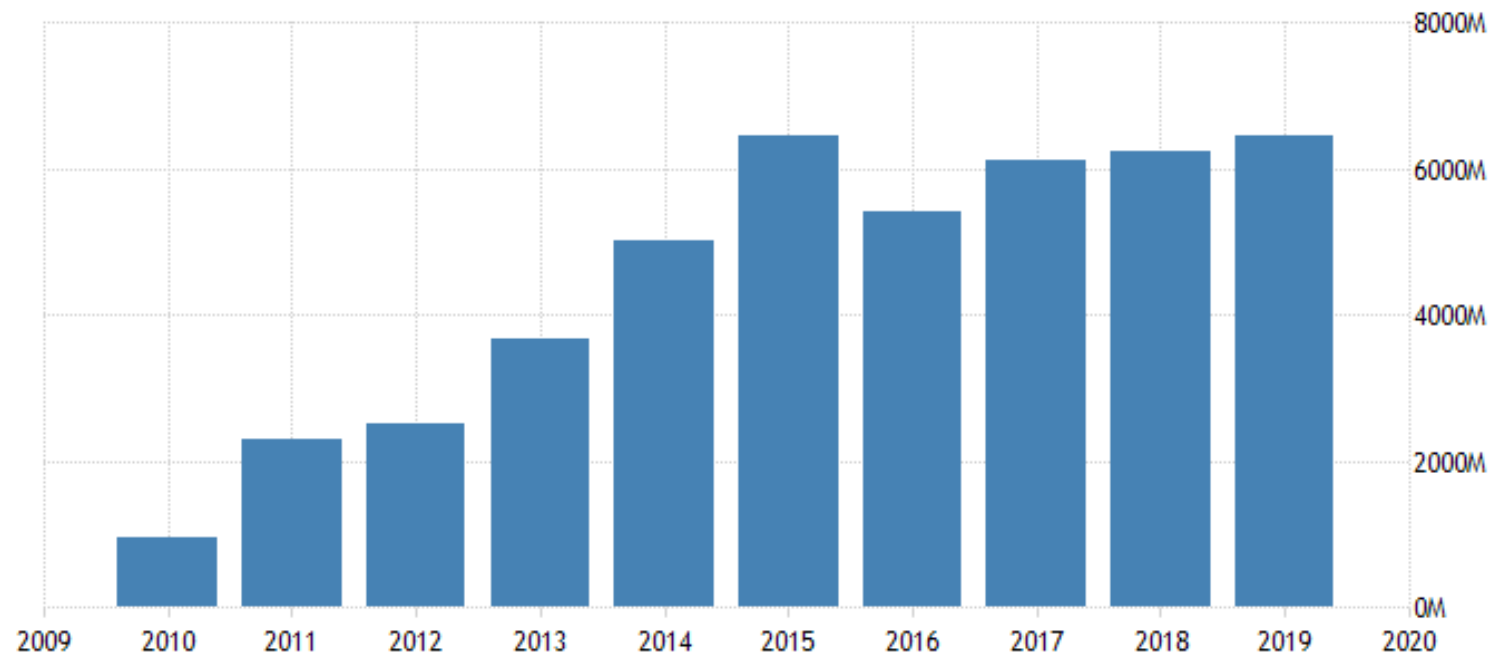

Figure 4. (Myanmar's Imports from China)

Source: https://tradingeconomics.com/myanmar/imports/china

However, one of the major obstacles to trade in Myanmar is the trade deficit. In the first seven months of the 2019-2020 fiscal years, the trade deficit was US \$ 1.2 billion, from October 1, 2019 to April 24, 2020 (Xinhua, 2020). Various programs are being implemented between the two countries to improve Sino-Myanmar trade relations. The 18th China-Myanmar Border Economic Trade Fair was held in December 2019. More than 2,000 Myanmar's products in more than 500 booths were shown in the China Import Expo last year, through which it has been proven that there is a rapid increase, in terms of trade between 
China and Myanmar. The trade exhibition also shows that there are a huge possibility of trade and investment, exports and imports, people to people contacts and cultural exchanges between the people of the two nations (Xinhua, 2020).

\begin{tabular}{|l|l|l|}
\hline Items & Value & Year \\
\hline $\begin{array}{l}\text { Machinery, nuclear reactors, } \\
\text { boilers }\end{array}$ & $\$ 830.44 \mathrm{M}$ & 2019 \\
\hline Manmade staple fibers & $\$ 782.34 \mathrm{M}$ & 2019 \\
\hline $\begin{array}{l}\text { Electrical, electronic } \\
\text { equipment }\end{array}$ & $\$ 716.05 \mathrm{M}$ & 2019 \\
\hline Iron and steel & $\$ 637.44 \mathrm{M}$ & 2019 \\
\hline $\begin{array}{l}\text { Vehicles other than railway, } \\
\text { tramway }\end{array}$ & $\$ 440.67 \mathrm{M}$ & 2019 \\
\hline Articles of iron or steel & $\$ 318.80 \mathrm{M}$ & 2019 \\
\hline Manmade filaments & $\$ 299.75 \mathrm{M}$ & 2019 \\
\hline Plastics & $\$ 257.33 \mathrm{M}$ & 2019 \\
\hline Fertilizers & $\$ 162.79 \mathrm{M}$ & 2019 \\
\hline Knitted or crocheted fabric & $\$ 146.34 \mathrm{M}$ & 2019 \\
\hline
\end{tabular}

Figure 5. Top 10 most imported products from China to Myanmar

Source: https://tradingeconomics.com/myanmar/exports/china

\begin{tabular}{|l|l|l|}
\hline Items & Value & year \\
\hline $\begin{array}{l}\text { Mineral fuels, oils, distillation } \\
\text { products }\end{array}$ & $\$ 1.89 \mathrm{~B}$ & 2019 \\
\hline $\begin{array}{l}\text { Pearls, precious stones, metals, } \\
\text { coins }\end{array}$ & $\$ 585.16 \mathrm{M}$ & 2019 \\
\hline $\begin{array}{l}\text { Edible fruits, nuts, peel of citrus } \\
\text { fruit, melons }\end{array}$ & $\$ 534.72 \mathrm{M}$ & 2019 \\
\hline Copper & $\$ 504.03 \mathrm{M}$ & 2019 \\
\hline Cereals & $\$ 311.62 \mathrm{M}$ & 2019 \\
\hline $\begin{array}{l}\text { Oil seed, oleaginous fruits, } \\
\text { grain, seed, fruits }\end{array}$ & $\$ 298.69 \mathrm{M}$ & 2019 \\
\hline $\begin{array}{l}\text { Edible vegetables and certain } \\
\text { roots and tubers }\end{array}$ & $\$ 285.95 \mathrm{M}$ & 2019 \\
\hline $\begin{array}{l}\text { Fish, crustaceans, Molluscs, } \\
\text { aquatics invertebrates }\end{array}$ & $\$ 230.23 \mathrm{M}$ & 2019 \\
\hline Live animals & $\$ 229.05 \mathrm{M}$ & 2019 \\
\hline Iron and steel & $\$ 220.14 \mathrm{M}$ & 2019 \\
\hline
\end{tabular}

Figure 6. Top 10 most Export products from Myanmar to China

Source: https://tradingeconomics.com/myanmar/exports/china 


\section{Macrothink}

\section{China's Geostrategic and Trade Interests in Myanmar}

Although, Sino-Myanmar diplomatic relations were established in 1950, friendly relations between the two countries were established in the pre-Christian era. In recent times, it has expanded rapidly. Ancient Chinese proverb, "a good neighbor is better than a dwelling relative". Trade relations between China and Myanmar continue to grow on the basis of this policy. The Greater Mekong Sub-region Economic Cooperation was established in 1992 at the initiative of China. The aim was to increase transport, telecommunications, agriculture, trade and investment through mutual cooperation and understanding among the four countries along the Mekong River, including Myanmar (Weifend, 2016)).

China is Myanmar's largest trading partner, and is one of the most trusted sources of foreign investment over the past few decades. As of December 2019, Chinese investment in Myanmar was $25 \%$ of total investments. As of June 30, 2020, China's investments in Myanmar have grown at US \$ 21350.668 Million, which are $24.78 \%$ of Myanmar's total foreign investments (DICA, 2020). Not only China, but many other countries in the world have increased their investments in Myanmar. The below graph shows the comparative position of the first 10 countries which invested in Myanmar till 30 June, 2020. At the same time, the investment sectors are also presented through this pie chart.

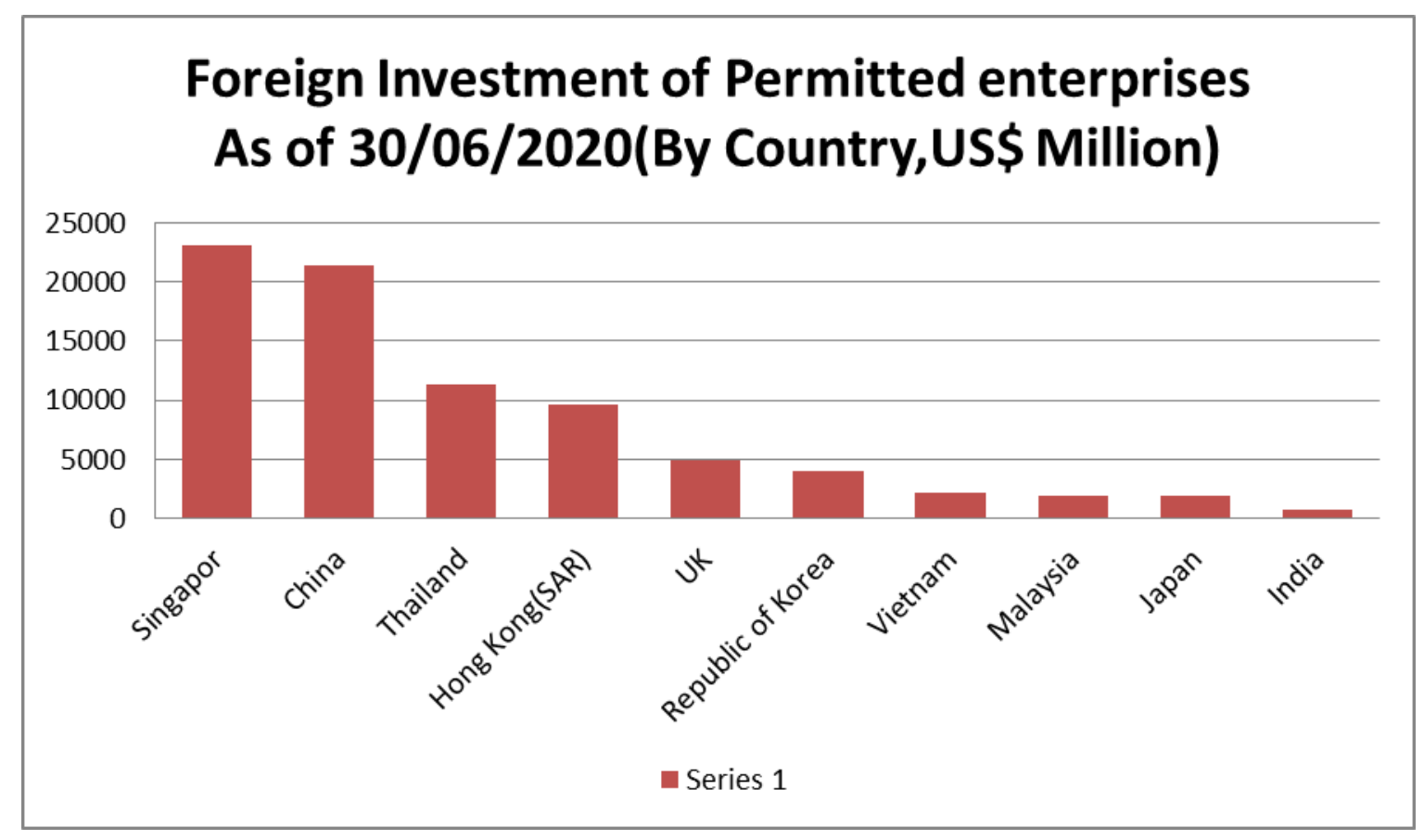

Figure 7. Foreign Investment in Myanmar by Country

Source: DICA (2020), Directorate of Investment and Company Administration. 


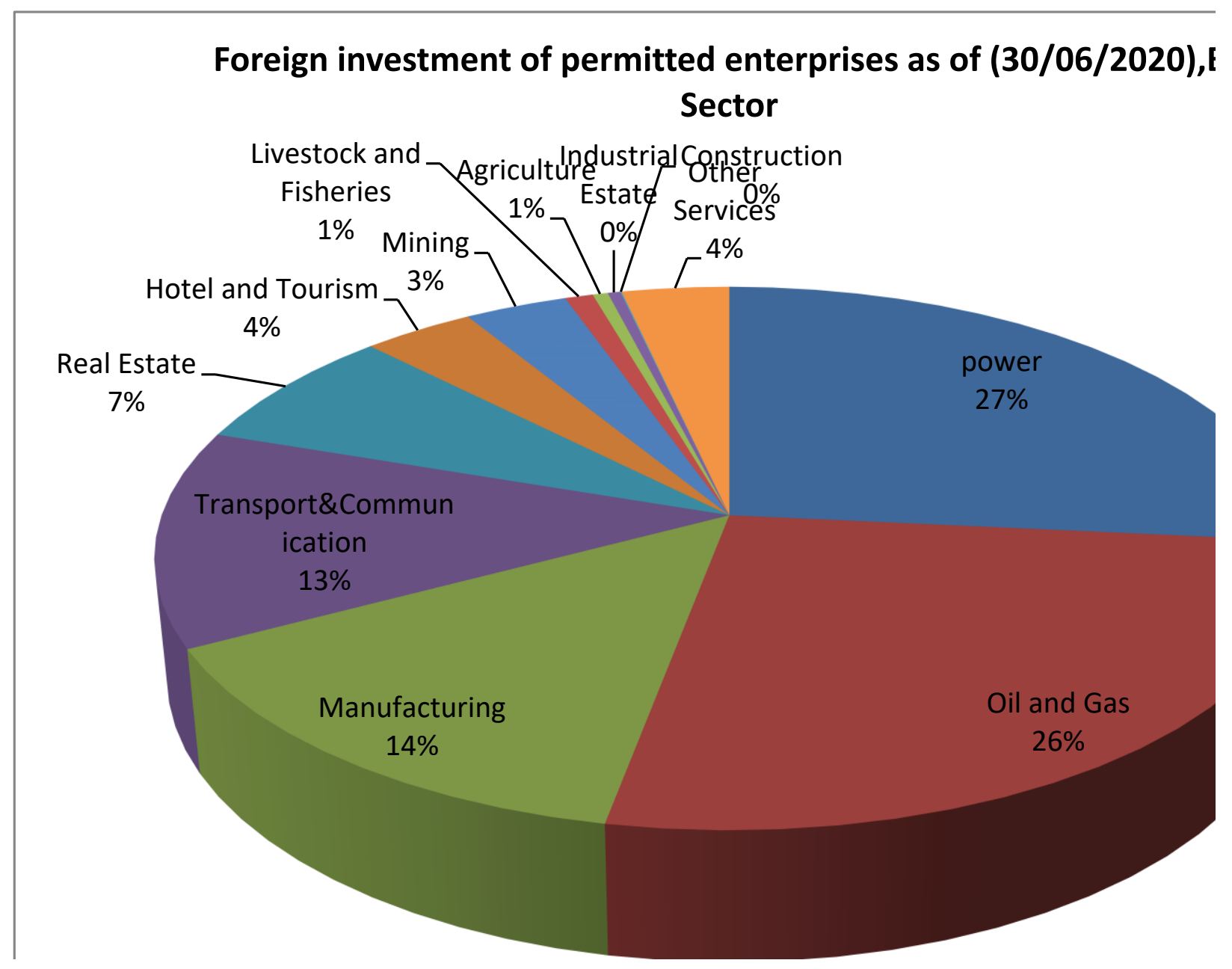

Figure 8. Foreign Investment in Myanmar By sector

Source: DICA (2020), Directorate of Investment and Company Administration.

At the same time, if we look at the Chinese investment in Myanmar over the past few decades, we can see that Chinese investment in Myanmar reached its peak in FY 2010-11 after President Thein Sein took office. Since then, Myanmar has adopted a precautionary policy on Chinese investment. At present, China has changed its investment policy in Myanmar. In the recent years, Chinese investment has been concentrated in the exploration and production of oil and gas, construction of hydropower projects, extraction and development of mineral resources, and construction of transmission lines, establishment of manufacturing industries, etc. (The Irrawaddy, 2019). An image of Chinese-invested projects in various fields in Myanmar is shown through visualization: 
- Two hydropower projects

- Monywa Letpadaung copper mines

- Monywa Sabetang and Kyisintaung copper mines

- Two mining projects

- Four hydropower projects

- Industrial park

- Deep sea port

- Oil and Gas pipeline

- New Yangon City Development

- Elevated railway project

- Plantation

- Farm (agricultural-based)

- IT-based projects

Hydropower and Dam Focused Agriculture and Plantation Focused

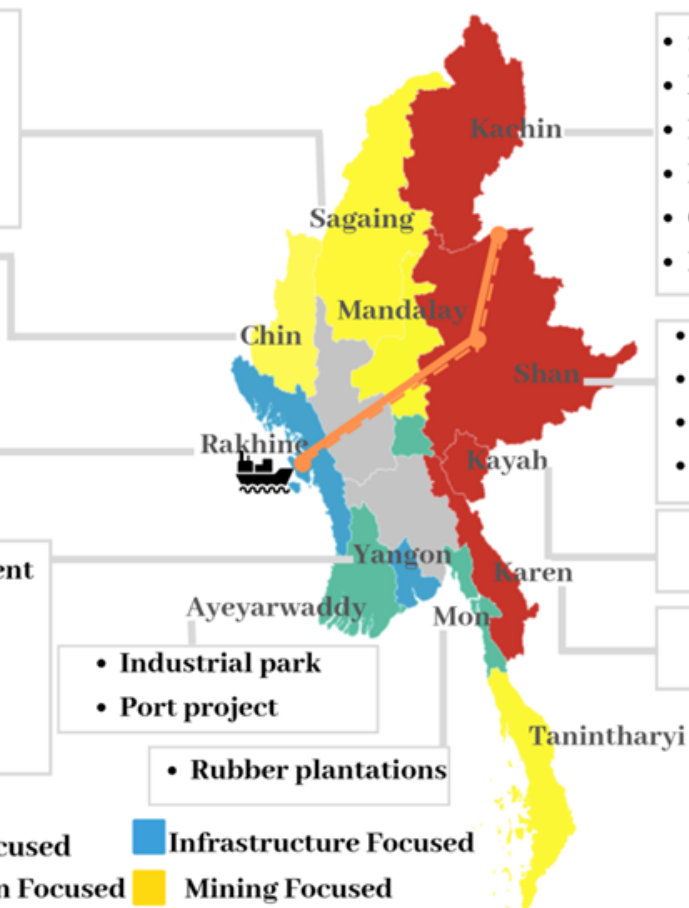

- 18 hydropower/dam projects

- Mega industrial park

- Border Economic Zone

- Banana plantations

- Cassava and sweet potato plantation

- Rare earth

- 13 hydropower/dam projects

- Tigyit Coal Mine and Power Plant

- Cassava and sweet potato plantation

- Rubber plantations

- Two hydropower projects

- Two hydropower projects

Figure 9.

Source: The Irrawaddy, 25 January, 2019

On the other hand, from 1988 to 2018, China has become the largest trading partner country for the various investments in Myanmar. Significant investments in Myanmar are in the areas of Hydropower, Oil and Gas, Mining, Agriculture. Thirty-three years of Chinese investment is shown below:

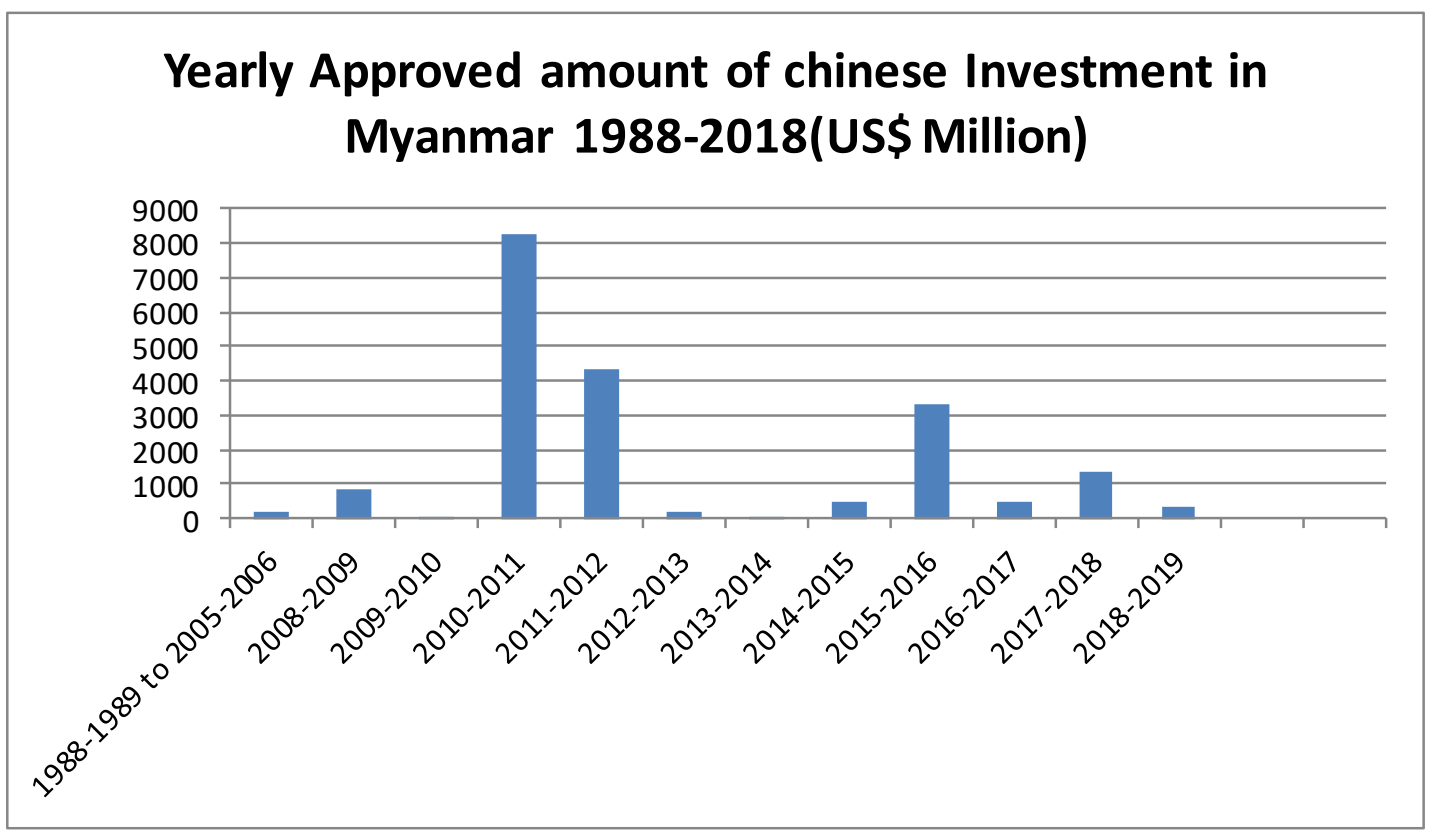

Figure 10. Chinese Investment in Myanmar

Source: The Irrawaddy, January 25, 2019. 


\section{Macrothink}

Journal of Public Administration and Governance

ISSN 2161-7104 2020, Vol. 10, No. 3

However, in 2001, China adopted the 'Go Global' policy to encourage domestic entrepreneurs to invest abroad. Between 2005 and 2010, Chinese FDI in Myanmar increased at a significant rate. In 2011, China became Myanmar's largest trading partner, ranking third behind Thailand and Singapore three years ago. However, after the change of the government in 2011, Chinese investment was hindered in many areas, such as the Myitsone Dam and the Letpadaung Copper Mine Project. Chinese investment declined to US \$ 217.8 million in 2011 from US \$ 875.6 million in the previous fiscal year. Chinese investors monitored the situation until the election of 2015. The Chinese investment in Myanmar is mainly focused on Hydropower, Oil and Gas, Mining. According to the Myanmar Embassy, as of 2011, 63\% of Chinese investment was in the power sector, and 36\% in the oil and gas sector. These three sectors account for $99 \%$ of Chinese investment (Dunn, Ji \& Peng, 2016).

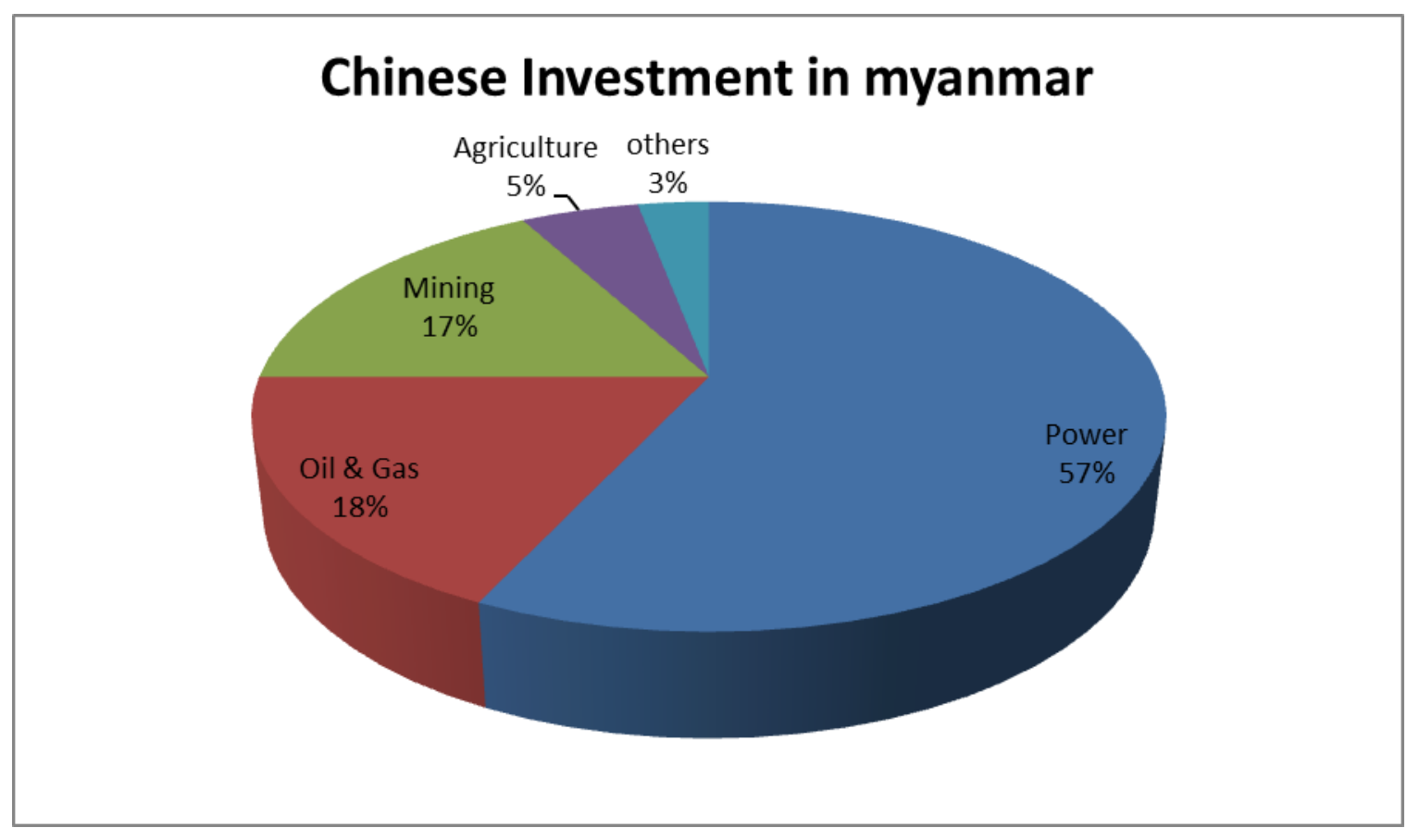

Figure 11. Chinese Investment in Myanmar by Sector

Source: The Irrawaddy, January 25, 2019.

If we analyze China's investment by sector, it shows that $57 \%$ are in the power plantation sector, $18 \%$ are in oil, and gas sectors, and $17 \%$ investment are in mining sector (The Irrawaddy, 2019).

\section{Chinese Investment in Myanmar's Hydropower Sector}

At least 45 Chinese multinational companies (MNCs) are involved in the construction of substations and transmission lines at about 63 hydropower projects in Burma. The most notable of which is the Tasang Dam (ERI, 2008) on the banks of the river Salween with a generating capacity of 7100 (MW). During the recent visit of Chinese President, Xi JinPing to Myanmar (January 17-18, 2020), an agreement was signed to build an integrated LNG 
power project with an investment of US \$ 2.6 billion. The notable Chinese-invested projects in Myanmar include Sinohydro's US\$ 1 billion 1200 (MW), Hat Gyi Dam in 2006, Farsighted Group's 2400 (MW) project in April 2007, and Sinohydro Company's 790 (MW) Yeywa dam in Mandalay province in 2000. China also invested in Sinohydro-Kun, Kyauk, Nam Hkam, Paunglaung, Tarpein I, Thapan seik and Zawgyi Dam projects. Moreover, in April 2008, Sinohydro, China Southern Power Grid Company, China Three Gorges Project Company, and Salween River contracted some agreements with Myanmar to construct the these hydropower projects (Earth Rights International (ERI), 2008).

In 2004, Yunnan Machinery \& Equipment Import and Export Co (YMEC) started production of 1420 (MW) in Shweli I, II, III blocks in Shan state along the Chinese border. Chinese companies are also involved in the construction of six dams, including N'Mai Hka, Mali Hka and Irrawaddy River in Kachin State, where 13360 (MW) of electricity will be produced. The Yunnan Machinery \& Equipment Import and Export Company (YMEC), one of the leading Chinese investment companies in Myanmar, has been involved in more than 25 projects since 1990. Of those, Ching Hkram, Chinshwehaw, Dattawgyaing, Hopin, Kunhein, Kunlon and others are remarkable. China is one of the countries which have scarcity in the energy sector, and it is worried about its future energy needs. Therefore, China has taken some initiatives to build up some power plants in Myanmar to meet China's growing electricity demand. For that reason, when Shweli I Dam started production in 2009, 85\% was exported to China. Similarly, the China Power Investment Corporation (CPI) on the Ayeyarwady River in Kachin State, Myanmar, allocated US \$ 20 billion for the constructions and implantation of the projects. The electricity produced in the plants will be exported to China.

The power plantation projects that are being built in the different states of Myanmar have some negative impacts on the local economy, host people and environment as well. Thus, there is observed some political instability and social disorder in the region. Sometimes, local people come to the streets, and involve themselves in protesting against these Chinese projects. As a result, President Thein Sein declared that, the Myitsone project would be closed on September 29, 2011 (Mizuno, 2016).

\section{Chinese Investment in Myanmar's Oil and Gas Sector}

The China-Myanmar pipeline project began in 2004, and there was a significant breakthrough when China National Petroleum Corporation (CNPC) began importing natural gas from the Middle East to China, and began supplying gas locally to Myanmar. The length of this pipeline is $2520 \mathrm{~km}$ including $793 \mathrm{~km}$ in Myanmar, and $1727 \mathrm{~km}$ in China. Myanmar is currently being considered as an important destination for Chinese investments in oil and gas sector in Southeast Asia after Indonesia. The Chinese companies' investments in Myanmar have grown increasingly since its inception in 2000, and the oil sector has become one of the driving forces behind Myanmar's rapidly developing economy. According to a 2008 Earth Rights International report, 16 Chinese companies, including CNPC, CNOOC and Sinopec are involved in 21 onshore and offshore oil and natural gas projects in Myanmar. These include Sinopec, China National Petroleum Corporation (CNPC) and China National Offshore Oil Corporation (CNOOC) (ERI, 2008). 
In August 2007, the Burmese military government decided to sell Petro-China gas from Arakan's Shwe gas field at a lower price compared to other companies. CNPC has signed a memorandum of understanding for five gas fields in Arkan with Myanmar State Oil \& Gas Enterprise (MOGE). On the other hand, companies under CNOOC have signed MoUs for gas exploration and production for six Arkan blocks. Both Sinopec and Petro-China conducted exploration of gas along the Arkan coast in 2006 and 2007. CNPC and Sinopec began work on the gas exploration as well as the pipeline. There has been built a gas pipeline of 2380 kilometers from Kyaukphyu port of Arakan state to Kunming in China. Apart from gas pipe line, the Sinopec has already signed a US \$ 1 billion contract to set up the oil line, and CNPC has signed a Memorandum of Understanding (MoU) with MOGE to build a crude oil terminal in Myanmar.

\section{Chinese Investment in Myanmar's Mining Sector}

It is difficult to assess the involvement of Chinese companies in mining sector in Myanmar, because the coalfields are located in the remote areas, and in many cases public access is restricted by the military. In Kachin and Shan states, Chinese Northern Star, Sea sun star and the Standing Company Limited are engaged in mining activities. In addition, 10 Chinese multinational companies have been involved in six large minefields for the past five years. The Tagaung Taung Nickel Deposit of Mandalay Division is largely controlled by China Nonferrous Metal Mining Company through investing US \$ 600 million for 40 million tons of nickel. The China's National Reform and Development Council approved the project in 2008 for investment in mines. The project was funded by China Exim Bank and China Development Bank (ERI, 2008).

At the same time, also Kingbao (Jinbao) Mining Company signed an agreement with the Ministry of Mining to conduct an exploration in Chin state, Letpadaung Bopper Deposit and Mwetaung Nickel deposit. Yunnan Machinery \& Equipment Export and Import Company has signed an agreement with Myanmar's Ministry of Mines for investment in Namtu-Bawtwin Mineral deposit in Shan Province. At the same time, the Chinese state-owned China North Industries Corporation (NORINCO) and the Union of Myanmar Economic Holdings Limited (UMEHL) have jointly invested US \$ 1.065 billion in the Letpadaungtaung Copper mine. In July 2013, the Myanmar Investment Commission approved an agreement. It says Wanbao's share is $51 \%$; but, its profit will be $30 \%$. The company also invested US \$ 1 Billion for social responsibility and US $\$ 2$ billion for environmental protection (ERI, 2008).

\section{Sino-Myanmar Military and Strategic Relations}

After the student movement in 1988 and the re-imposition of military rule in Myanmar in the 1990s, Sino-Myanmar military relations improved due to international sanctions. The relationship began with the purchase of jet fighters, armored vehicles and naval ships. China and Myanmar subsequently set a common goal of increasing their capabilities to the Indian Ocean through military cooperation. Myanmar's military spending fluctuated from 2012 to 2013. At the same time, military spending increased to US \$ 3268.6 million from US \$ 3801 million in 2015. On the other hand, it decreased to US \$ 3634.3 million in 2016 and US $\$ 2604.1$ Million in 2017. According to the National Defense and Security Council, one of the 
reasons for the increase in military spending in Myanmar is the rise of various rebel groups (Pike, 2015). In 2014, Myanmar spent 23.2 percent of its national budget on cracking down on insurgent groups. Between 2014 and 2016, 61 percent of Myanmar's weapons were imported from China (Tourangban \& Amin, 2019).

In addition, high-level visits between the two armed forces Tatmadaw and the PLA (People's Liberation Army) are playing an important role in the field of military relations. Army Chief Min Aung Hlaing paid visits to China 15 times during his tenure (The Diplomat, April 12, 2019). In the aftermath of the Rohingya crisis, Myanmar's army chief, Senior General Min Aung Hlaing praised bilateral relations during his visit to Beijing in 2019, and expressed support for the Chinese BRI. In exchange, Chinese President Xi Jinping assured security and development cooperation. A significant aspect of this relationship is the opportunity to train up Myanmar's officers at PLA's Staff College and Defense College. Also in 2017, for the first time, the Chinese navy began joint exercises with Myanmar where three Chinese warships took part (Ernasari \& Pertahanan, 2018).

While, China has been one of Myanmar's leading arms suppliers since 1989. Reliance on China has increased, especially due to Western sanctions, and old arms suppliers have been reluctant to supply arms to Myanmar. China is thought to have supplied about US \$ 4 billion of weapons, notably warships, small arms, anti-aircraft guns, combat aircraft, main battle tanks, armored personnel carriers, etc. According to SIPRI, 68\% of Myanmar's arms are imported from China during the period of 2013 and 2017. These include armored vehicles, surface-to-air missile technology, radar, unmanned drones and other military equipment. Myanmar also imports weapons from India and Russia. During a visit to Myanmar in 2018, Russia's defense minister signed an arms deal worth about US \$ 200 million, including seven SU-30 air craft. China was established as Myanmar's largest arms' supplier from 1990 to 2016 (Asrar, 2017). 
Most of Myanmar's military imports come from China, Russia, Israel, Ukraine and India.

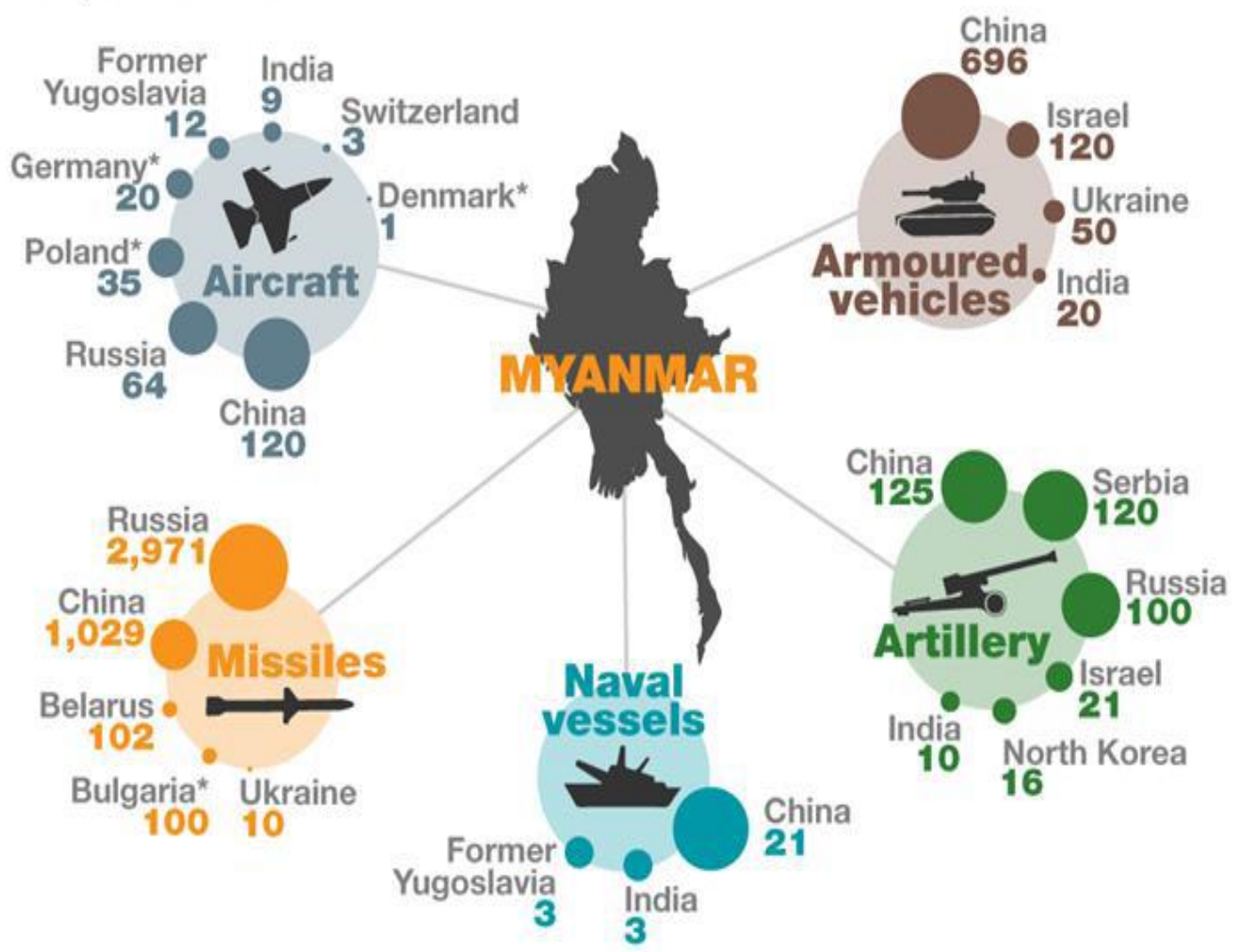

Figure 12. Myanmar arms trade 1990-2016

Source: Ernasari \& Pertahanan (2018)

The cost of transporting arms is also relatively low for China's geographic proximity to Myanmar. The above data shows that from 1990-2016; China supplied 120 aircraft, 1029 Missiles, 21 Naval Vessels, 125 Artillery and 696 Armored Vehicles.

\section{Limitations of China-Myanmar Relations}

1. Drugs are one of the major problems in promoting Sino-Myanmar relations. China is particularly a victim of the drug trade in the border areas of Myanmar. On February 14, 2006, State Council Premier, Wen Jiabao spoke with Myanmar Prime Minister, Soe Win on the initiative. He said, the spread of drugs in the border areas posed a serious health risk to the local population. China expects that the two countries will sign an agreement on the drug control. Myanmar is the world's second largest producer of illicit opium. In the areas which are controlled by the rebel groups, opium poppy cultivation is predominant. Opium production was valued at US\$ 58 million in 2005, accounting for 0.9\% of Myanmar's GDP (United Nations Office on Drugs and Crime report, 2005).

2. Myanmar is also a major source of heroin in China. Those heroins enter China via Kunming, and enter into the various U.S. markets via Hong Kong, the South China Sea, and Taiwan. 
3. Myanmar is one of the countries in Southeast Asia where the chances of survival at birth are low. It is also one of the fastest growing HIV-infected countries in the world today. UNIDS estimates in 2006 that the HIV infection rate among 15 to 49 year-old was $1.3 \%$ (UNAIDS report, 2006). HIV transmission from Myanmar to China, drug addiction and humanitarian impacts could hamper China's economic activities in the region to some extent.

4. The Rohingya problem is one of the main concerns for Chinese investment in Myanmar. Most of the China's major investments are in Rakhine State. Rakhine also needs stability for geostrategic and economic reasons. That's why clashes between ARSA and Myanmar forces in Rakhine have hampered China's trade.

5. Another obstacle to Sino-Myanmar relations is ethnic violence in Shan, Chin and Rakhine provinces, but most of the China's investment is in these areas. The Shan State Army (SSA) and the Restoration Council of Shan State (RCSS) are constantly fighting for self-control. The state of Chin, on the other hand, is located on the eastern border of south-eastern India and southeast of Bangladesh. The region is home to guerrilla warfare, including the Chin National Front (CNF), The Chin National Army (CNA) and The Naga National Council (NNC), among others (Islam, 2018). Myanmar's security forces have clashed with the Arakan Liberation Party and the ARSA in Arakan Province, threatening Chinese investment.

\section{Future of China-Myanmar Bilateral Relations}

Myanmar is very important country for China, because of its geostrategic location; it also needs China's help to improve its economy from international isolation. Especially after the 2015 elections, Myanmar tried to adopt 'Look Western Policy', but after the Rohingya massacre in August 2017, in the face of international criticism, Myanmar has again been dependent on China. Following this, the President of China visited Myanmar on January 17-18, 2020, and pledged to improve their relationship. They called each other (Paukphaw) brothers and, signed 33 agreements for economic development. Myanmar has a huge amount of natural resources. China is interested in strengthening its position through the extraction of these resources, especially the Rakhine-Beijing link, which is very important for China and Myanmar in terms of economic progress. Taking advantage of this opportunity of cooperation between the two nations, Myanmar can be greatly benefitted from the China's investment in the different projects. It is firmly believed that Myanmar has huge amount of natural resources though which it can attract an enormous foreign investment where China can play a pivotal role in the economic development of Myanmar. Considering the Myanmar's geostrategic location and natural resources, it can be said that Myanmar can turn its poor economy into a developed one through trade and investment, and through exploring natural resources in the Bay of Bengal, and Rakhine including the other states of Myanmar.

\section{Conclusion}

The emergence of China in terms of economic and military capabilities as a force to be reckoned with in the current world system is a cheering news for the world politics. The Belt and Road Initiative (BRI) scheme is one of the means to establish itself as a 'super power' in the world. Myanmar is China's geo-strategic partner in implementing this initiative. The 
economic corridor from Rakhine to Kunming in Yunnan Province, China, and the gas and oil pipeline are very important. Especially, the Bay of Bengal and the Indian Ocean are very pivotal in importing oils from the Middle Eastern and African countries to the Chinese territories, particularly to the province of Yunnan. The ports and highways of Myanmar are used for China's exports and imports, because Myanmar is geographically connected with China. In this context, the Bay of Bengal and Myanmar's ports are used as an alternative route of the Malacca Strait. China also needs to maintain good relations with other neighbors including Myanmar, and it also wants peace and political stability in the region in order to establish its own geo-strategic dominance in the region. At the same time, Myanmar lags behind others in the region economically due to its long military rule. China has been investing in Myanmar's oil, gas and mineral resources since the 1990s. Myanmar is also one of the major investment sectors for China's trade and investment. Myanmar, on the other hand, has been limited to exporting timber, agricultural products and marine fishes to China for its agro-based industries, since its independence. As a result, there is a huge trade deficit between Myanmar and China. At the same time, various Chinese development projects have become a threat to Myanmar's environment and people's livelihoods. Under these circumstances, Myanmar will be able to establish itself as a new partner in the world economy, if it can maintain a long-term relationship based on mutual interests by establishing a balanced trade relationship with China.

Considering the above discussion on Sino-Myanmar relations, we can say that the relationship between the two nations is very strong in the context of geostrategic and economic aspects. Therefore, without the Chinese involvement and cooperation, Bangladesh will not be able to deal with the Rohingya issue. And the country has to face huge troubles in the process of Rohingya repatriation unless China provides with the diplomatic cooperation to Bangladesh. Thus, Bangladesh needs to maintain strong friendly relations with China and Myanmar to resolve the Rohingya issue amicably.

\section{References}

Ahamed, A., \& Rahman, M. S. (2020). A Review of China-India Geopolitical Relations in the Context of Belt and Road Initiative (BRI). Journal of Economics and Finance

Asrar, S. (2017). Who is selling weapons to Myanmar?. Al Jazeera, 16.

Bert, W. (2004). Burma, China and the USA. Pacific Affairs, University of British Columbia, 77(2), 263-282,

DICA. (2020). Directorate of Investment and Company Administration (Myanmar). Retrieved 28 July 2020, from https://www.dica.gov.mm/en/taxonomy/term/38

Dunn, C., Ji, L., \& Peng, K. (2016). Chinese Investments in Myanmar: A Scoping Study. China: Global Environmental Institute.

Earth Rights International. (ERI). (September, 2008). China in Burma: The Increasing Investment of Chinese Multinational Corporations in Burma's Hydropower, Oil and Natural Gas, And Mining Sectors. 
https://www.earthrights.org/sites/default/files/publications/China-in-Burma-update-2008-Eng lish.pdf>

Ernasari, C., \& Perwita, A. A. B. (2018). SINO-MYANMAR DEFENSE COOPERATION AND CHINA'S EFFORTS TO BOLSTER ITS SPHERE OF INFLUENCE IN THE INDIAN OCEAN (2013-2017). Jurnal Pertahanan: Media Informasi ttg Kajian \& Strategi Pertahanan yang Mengedepankan Identity, Nasionalism \& Integrity, 4(3), 120-135. https://doi.org/10.33172/jp.v4i3.290

Frontier Myanmar, (September 26, 2018) \& (March 8, 2019). https://www.frontiermyanmar.net/en/

Fuller, T. (2011). Myanmar backs down, suspending dam project. New York Times, 30.

Geng, L. (2006). 'Sino-Myanmar Relations: Analysis \& Prospects.' In The Culture Mandala, 7(2). http://www.international-relations.com/CM7-2WB/Sino-Myanmar.htm

Han, E. (2020). Myanmar's Internal Ethnic Conflicts and Their Implications for China's Regional Grand Strategy. Asian Survey, 60(3), 466-489. https://doi.org/10.1525/as.2020.60.3.466

Houqe, M. A. (1 September, 2016). "Bangladesh-Myanmar relations: Open all windows to look East." Retrieved from http://www.theindependentbd.com/printversion/details/44347.

Islam, M. S., Ailian, H., \& Jie, Z. (2018). Major Challenges and Remedies in Building the Bangladesh-China-India-Myanmar Economic Corridor. China Quarterly of International Strategic Studies, 4(04), 613-629. https://doi.org/10.1142/S2377740018500306

Lintner, B. (2000). The Golden Triangle Opium Trade: An Overview. Asia Pacific Media Services, 12. Retrieved from http://asiapacificms.com/papers/pdf/gt_opium_trade.pdf

Mizuno, A. (2016). Economic Relations Between Myanmar and China. In The Myanmar Economy (pp. 195-224). Springer, Tokyo. https://doi.org/10.1007/978-4-431-55735-7_8

Mizzima, (7 March, 2020). Dangers of a Chinese debt trap for Myanmar, http://mizzima.com/article/dangers-chinese-debt-trap-myanmar

Pike, J. (2015),'Myanmar Defence spending. Retrieved from https://www.globalsecurity org/military/world/Myanmar/budget.html

Rahman, M., Akhter, K., \& Saif, N. G. (2015). Trade and Transport Facilitation in Bangladesh An Audit of the State of Play.

Ramachandran, S. (13 April, 2020). The China-Myanmar Economic Corridor: Delays Ahead Publication: China Brief, Volume: 20 Issue: 7, The Jamestown Foundation, Washington, DC, https://jamestown.org/program/the-china-myanmar-economic-corridor-delays-ahead/

Reed, J. (January 18, 2020). China and Myanmar sign off on Belt and Road projects, Financial Times. https://www.ft.com/content/a5265114-39d1-11ea-a01a-bae547046735\#

South China Morning Post, (18 January, 2020). Chinese President Xi Jinping wraps up 


\section{Macrothink}

Journal of Public Administration and Governance

ISSN 2161-7104

2020, Vol. 10, No. 3

Myanmar visit with string of infrastructure deals, including strategic Indian Ocean port, https://www.scmp.com/news/china/diplomacy/article/3046694/chinese-president-xi-jinpingwraps-myanmar-visit-string

Taylor, R. H. (1987). The state in Burma, Honolulu; University of Hawaii Press,1987,p.13

The Diplomat, (April 12, 2019). China, Myanmar Extol 'Eternal' Friendship as Commander-in-Chief Visits Beijing, https://thediplomat.com/2019/04/china-myanmar-extol-eternal-friendship-as-commander-in-c hief-visits-beijing/

$\begin{array}{llll}\text { The Financial } & \text { Express, } & \text { 2019). }\end{array}$ https://today.thefinancialexpress.com.bd/public/?date=03-11-2019

The Irrawaddy, (14 May, 2019). China-Backed Muse-Mandalay Railway to Cost \$9 Billion, https://www.irrawaddy.com/news/burma/china-backed-muse-mandalay-railway-cost-9-billion .html

The Irrawaddy, (25 January, 2019). Info graphic: 30 Years of Chinese Investment in Myanmar, file:///D:/Article\%202020/China-mayanmar/Infographic_\%2030\%20Years\%20of\%20Chines e\%20Investment\%20in\%20Myanmar.html

Tourangbam, M., \& Amin, P. (2019). China's Dynamic Grip on Myanmar. The Diplomat, 7.

Trading Economics, (2019). Myanmar exports to China https://tradingeconomics.com/myanmar/exports/china

UNAIDS, (2006), Report on the Global AIDS Epidemic: Overview of the Global AIDS Epidemic, 2006, p. 413.

United Nations Office on Drugs and Crime report, (2005). Available via http://www.unis.unvienna.org/unis/pressrels/2005/unisnar923.html

Weifeng, Z. (2016). New Dynamics in sine Myanmar relations. Global Asia, 11(3). Retrieved from https://www.globalasia.org,

Xinhua, (20 July, 2020). Myanmar's border trade reaches over 8.6 bn USD in first 10 months of FY 2019-20, http://www.xinhuanet.com/english/2020-07/20/c_139227208.htm

Zhou, W., \& Cuyvers, L. (2011). Linking international trade and labour standards: the effectiveness of sanctions under the European Union's GSP. J. World Trade, 45, 63.

\section{Copyright Disclaimer}

Copyright for this article is retained by the author(s), with first publication rights granted to the journal.

This is an open-access article distributed under the terms and conditions of the Creative Commons Attribution license (http://creativecommons.org/licenses/by/4.0/). 